\title{
Apoptosis Induced by N-Nitrosamines in Two Cancer Cell Lines
}

\author{
Paloma Morales, Nuria Arranz, Ana I. Haza
}

Departamento de Nutrición, Bromatología y Tecnología de los Alimentos, Facultad de Veterinaria, Universidad Complutense de Madrid, Madrid, Spain.

Email: hanais@vet.ucm.es

Received May $20^{\text {th }}, 2010$; revised July $1^{\text {st }}, 2010$; accepted July $3^{\text {rd }}, 2010$.

\begin{abstract}
In the present study, we investigated the induction of apoptosis by N-nitrosopyrrolidine (NPYR) and N-nitrosodimethylamine (NDMA) in two human cell lines: HL-60 (leukemia) and HepG2 (hepatoma). Apoptotic cells were identified by: 1) chromatin condensation, 2) flow cytometry analysis and 3) poly (ADP-ribose) polymerase cleavage. Both cell lines exhibited morphological changes consistent with apoptotic events following treatment with $N$-nitrosamines. Flow cytometry analysis showed that both $N$-nitrosamines induced apoptotic cell death in a concentration and time dependentmanner. NPYR was stronger than NDMA, since it induced a significant apoptotic cell death after $72 \mathrm{~h}$ starting from a concentration of $10 \mathrm{mM}$, whereas NDMA was effective at $27 \mathrm{mM}$. Furthermore, NPYR and NDMA caused the cleavage of PARP in HL-60 cells whereas no PARP cleavage was detected in HepG2 cells. However, NPYR-and NDMAinduced cell death in HepG2 cells was prevented by specific caspase inhibitors. Caspase-8 mediated main pathway and was responsible for 76\% (NPYR) and 64\% (NDMA) inhibition of apoptosis. The data demonstrate that NPYR and NDMA induce apoptosis in HL-60 and HepG2 cell lines via caspase-dependent pathway.
\end{abstract}

Keywords: N-nitrosopyrrolidine, N-nitrosodimethylamine, Apoptosis, Caspases, HL-60 Cells, HepG2 Cells

\section{Introduction}

The N-nitroso compounds (NNC) are recognized as one of the most potent chemical mutagens and carcinogens present in environment and in food [1]. N-nitrosamines are NNC found in foodstuffs, drinking water, rubber products, drug formulations, tobacco and tobacco smoke [2]. Their precursors, nitrites and secondary amines, contained in many common foods, can react under acidic conditions of the stomach and also are produced in vivo by reduction of nitrates by bacteria [3].

The majority of N-nitrosamines tested has been shown to cause cancer at different organs in a variety of animal species and may be causative agents in human cancer [4]. N-nitrosopyrrolidine (NPYR) induces mainly liver tumours in rats [5] and is a weak pulmonary carcinogen in mice [6]. N-Nitrosodimethylamine (NDMA), the simplest and most widely occurring nitrosamine, has been shown to be a potent liver, lung and kidney carcinogen [7]. The metabolic activation of NPYR and NDMA to reactive intermediates by cytochrome $\mathrm{P} 450$ is required for the expression of their toxic potential [8]. The key activation pathway is cytochrome $\mathrm{P} 450$-catalyzed hydroxylation of the carbon $\alpha$ to the nitroso group [9].

Toxic effect of chemicals can lead to passive cell death or necrosis, or result in the active mechanism of apoptosis. Necrotic cell death is an unregulated process resulting from severe damage to the cell and is characterized by ATP depletion, cell swelling, lysis, and the release of intracellular contents resulting in tissue inflammation [10]. Apoptosis, often described as cell suicide [11], is important in carcinogenesis [12], atherogenesis [13] and a number of other diseases [14]. Apoptotic cell death is a complex process characterized by biochemical events and definite morphologic changes [15]. One of the earliest and most consistently observed features is the induction of a series of cytosolic cysteine proteases, known as caspases [16]. Activation of the caspase cascade leads to changes in the plasma-membrane, mitochondria and nucleus [17]. Among the family of ten or more different caspases, already described, caspase- 8 and -9 are involved in receptor mediated and intracellular (mitochondrial) pathways of apoptotic cascade, respectively. Different reports indicate that caspase- $3,-6$ and -7 
are the major effector caspases of apoptosis [18].

It is now evident that many environmental chemicals exert their toxicity via apoptotic cell signalling [19]. For instance, it has been demonstrated that numerous food mutagens [20-22] and tobacco specific N-nitrosamine [23] induce apoptosis. Moreover, apoptosis induced by carcinogens seems to have an important role in cancer development. In general, apoptosis of cells exposed to carcinogen compounds allows the removal of cells with extensive DNA damage. However, the removal of these cells may give survival and proliferating signals to the surrounding cells with less DNA damage. This may cause a selection of preneoplasic cells that have become more resistant to carcinogen-induced cell death [24]. NDMA causes the apoptosis of rat neutrophils in vivo [25] and their reactive intermediate metabolites cause cell death in P450 2E1-expressing cells by triggering apoptosis [26]. However, to our knowledge, there are not available data about NPYR induced apoptosis.

Thus, the aim of the present study was to investigate the induction of apoptosis by NPYR and NDMA in two human cell lines. The HepG2 hepatoma cell line has been reported to retain some of the drug metabolizing enzyme activities of normal hepatocytes and to increase mRNAs for specific P450 enzymes [27]. Since NPYR and NDMA require metabolic activation catalyzed by the cytochrome P450 for its mutagenicity and carcinogenicity, their actions have been well studied in the liver but there have been few studies in the immune system (blood circulatory system). Moreover, NDMA can influence the activity of the immune system [25]. For this reason, in addition to HepG2 cells, the leukemia cell line HL-60 was tested. This cell line has proven to be a good model for studying the apoptotic process induced by chemicals in lymphoid organs [28] and express relatively high levels of enzymatic isoforms of cytochrome P450 [29].

This study also addresses the role of caspases in $\mathrm{N}$-nitrosamines-induced apoptosis in HL-60 and HepG2 cells.

\section{Material and Methods}

\subsection{Chemicals}

$\mathrm{N}$-nitrosopyrrolidine (NPYR), N-nitrosodimethylamine (NDMA), dimethyl sulfoxide (DMSO), etoposide and acridine orange, were purchased from Sigma-Aldrich, Inc. (St. Louis, MO). The caspase inhibitors, Z-DEVD-FMK (caspase-3 inhibitor), Z-VEID-FMK (caspase-6 inhibitor), Z-IETD-FMK (caspase-8 inhibitor) and Z-LEHD-FMK (caspase-9 inhibitor) were obtained from BD Pharmigen (USA). For western blot analysis, polyclonal poly (ADPribose) polymerase (PARP) antibody was purchased from Alexis Biochemicals (Lausen, Switzerland) and secondary goat anti-rabbit conjugated to peroxidase was obtained form Chemicon (Temecula, CA). All other chemicals and solvents were of the highest grade commercially available.

Standards solutions of NPYR and NDMA $(500 \mathrm{mM})$ were prepared in mili Q water (Millipore, Japan). N-nitrosamines are potent carcinogenic agents, safety precautions were taken for proper handling and disposal of the chemicals.

\subsection{Cell Lines and Culture Conditions}

Human hepatocellular carcinoma cells (HepG2) and human peripheral blood promyelocytic leukemia cells (HL-60) were obtained from the Biology Investigation Center Collection (BIC, Madrid, Spain). HepG2 cells were cultured as monolayer in Dulbecco's Modified Eagle's Medium. HL-60 cells were maintained in RPMI 1640 Medium. The media were supplemented with $10 \%$ $\mathrm{v} / \mathrm{v}$ heat-inactivated fetal calf serum, $50 \mathrm{mg} / \mathrm{ml}$ streptomycin, $50 \mathrm{UI} / \mathrm{ml}$ penicillin and $1 \% \mathrm{v} / \mathrm{v}$ L-Glutamine. Culture medium and supplements required for the growth of the cell lines were purchased from GIBCO Laboratories (Life Technologies, Inc., Gaithersburg, MD 208849980). Controls included a medium control without Nnitrosamines as a negative control. Etoposide has been extensively studied [30] and was used in this study as a positive control ( $5 \mu \mathrm{M}, \mathrm{HL}-60$ cells; $100 \mu \mathrm{M}, \mathrm{HepG} 2$ cells) of apoptosis.

\subsection{Chromatin Condensation Assay}

To examine the effect of N-nitrosamines on nucleus chromatin condensation, HL-60 and HepG2 cells $(1 \times$ $\left.10^{6} / \mathrm{ml}\right)$ were treated with NPYR $(10-50 \mathrm{mM})$ or NDMA (27-135 $\mathrm{mM})$ at different incubation times $(24-72 \mathrm{~h})$. After treatments, the cells were stained with acridine orange $(5 \mu \mathrm{g} / \mathrm{ml})$ for 10 minutes and observed under a UV-visible fluorescence microscope (Axiostar plus microscope, Zeiss) as described by Gregory et al. [31]. Cells exhibiting brightly fluorescent condensed or fragmented nuclei were considered apoptotic. A total of 200 cells were counted in multiple randomly selected fields, and the percentage of apoptotic cells was then calculated.

\subsection{TdT-dUTP Terminal Nick-End Labeling (TUNEL) Assay}

Apoptotic cell death was also measured by the In Situ Cell Death Detection Kit, Fluorescein according to the manufacturer's protocol (Roche, Indianapolis, USA). HL-60 and HepG2 cells were treated with NPYR $(10,30$ and $50 \mathrm{mM})$ or NDMA $(27,68$ and $135 \mathrm{mM})$ for 24,48 and $72 \mathrm{~h}$. Briefly, $3 \times 10^{6}$ cells were washed with PBS and fixed in $2 \%$ formaldehyde in PBS $(1 \mathrm{ml})$ for 1 hour 
at room temperature. Cells were washed with PBS and incubated with permeabilization solution $(0.1 \%$ Triton $\mathrm{X}-100$ in $0.1 \%$ sodium citrate) for $2 \mathrm{~min}$ on ice. Subsequently, the cells were incubated with the TUNEL reaction mixture [50 $\mu \mathrm{l}$ of enzyme solution (TdT) and $450 \mu \mathrm{l}$ of label solution (fluorescein-dUTP)] for 1 hour at $37^{\circ} \mathrm{C}$ in the dark in a humidified atmosphere. During this incubation period, TdT catalyses the addition of fluorescein-dUTP to free 3'-OH groups in single- and double stranded DNA. Omission of TdT from the staining protocol constituted the negative control. After the cells were washed with PBS, the label incorporated into the damaged sites of DNA was detected using a FACS Calibur flow cytometer (Becton and Dickinson) and the CellQuest software. For each experiment $10^{4}$ cells were analyzed. To examine the effect of N-nitrosamines on nucleus chromatin condensation, HL-60 and HepG2 cells $\left(1 \times 10^{6} / \mathrm{ml}\right)$ were treated with NPYR $(10-50 \mathrm{mM})$ or NDMA (27-135 mM) at different incubation times (24-72 h). After treatments, the cells were stained with acridine orange $(5 \mu \mathrm{g} / \mathrm{ml})$ for 10 minutes and observed under a UV-visible fluorescence microscope (Axiostar plus microscope, Zeiss) as described by Gregory et al. [31]. Cells exhibiting brightly fluorescent condensed or fragmented nuclei were considered apoptotic. A total of 200 cells were counted in multiple randomly selected fields, and the percentage of apoptotic cells was then calculated.

\subsection{Western Blot}

After incubation of cells with NPYR (10,30 and $50 \mathrm{mM})$ or NDMA (27, 68 and $135 \mathrm{mM}$ ) for 24-72 h (HepG2), protein extracts were obtained with Nucbuster Protein Extraction Kit (Novagen, Darmstadt, Germany). Equal amounts of protein cell extracts $(30 \mu \mathrm{g})$ measured by the Non Interfering Protein Assay Kit (Calbiochem) were used for western blot analyses. Samples were resuspended in a buffer containing $63 \mathrm{mM}$ Tris- $\mathrm{HCl}, \mathrm{pH} 6.8$, $10 \%$ glycerol, $1 \%$ 2-mercaptoethanol, $2 \%$ sodium dodecyl sulfate (SDS) and $0.025 \%$ bromophenol blue and boiled for $15 \mathrm{~min}$. Proteins were resolved on a $10 \%$ sodium dodecyl sulfate-polyacrylamide gel and electroblotted onto an immune-blot PVDF membrane (Bio-Rad Laboratories) at $119 \mathrm{~V}$ for 1 hour and $15 \mathrm{~min}$ in Tris glycine buffer $(25 \mathrm{mM}$ Tris, $192 \mathrm{mM}$ glycine, $20 \%$ methanol, $\mathrm{pH}$ 8.3). Equal protein loading and the integrity of transfer were confirmed by Blot-Fast-Stain (Chemicon, Temecula, CA). Subsequently, the membranes were blocked overnight in milk block buffer (PBS, $0.2 \%$ Tween, $10 \%$ non fat dry milk) and then incubated with polyclonal poly (ADP-ribose) polymerase (PARP) antibody diluted 1:1000 in milk block buffer on a plate shaker for $1 \mathrm{~h}$ at room temperature. The membranes were then washed three times $(10 \mathrm{~min}$ each $)$ in milk block buffer, and goat anti-rabbit peroxidase conjugated diluted 1:3000 in milk block buffer was applied to the blots for 1 $\mathrm{h}$ at room temperature with shaking. Then, the blots were washed as described above and one more time with PBS-Tween. Blots were developed using the super signal substrate (Pierce, Rockford, IL) and chemiluminiscence was directly detected using Bio-Rad Fluor S instrument and analysed used the Bio-Rad quantity one software package.

\subsection{Caspase Activity}

To address the significance of caspases activation in Nnitrosamines-induced apoptosis in HepG2 cells, we used permeable, specific and potent caspase inhibitors, Z-DEVD-FMK (caspase-3 inhibitor), Z-VEID-FMK (caspase-6 inhibitor), Z-IETD-FMK (caspase-8 inhibitor) and Z-LEHD-FMK (caspase-9 inhibitor). HepG2 cells were treated with $50 \mathrm{mM}$ NPYR ( $48 \mathrm{~h}$ ) or $68 \mathrm{mM}$ NDMA (72 h) in the presence or absence of $100 \mu \mathrm{M}$ of caspase inhibitors. After the incubation, the percentage of apoptotic cells was determined by TUNEL assay and flow cytometry.

\subsection{Statistical Analyses}

The Student's t-test was used for statistical comparison and differences were considered significant at $\mathrm{p} \leq 0.01$. Descriptive and graphical methods were used to characterize the data. All tests were performed with the software package Statgraphics Plus 5.0.

\section{Results}

\subsection{Analysis of Morphological Changes Induced by NPYR and NDMA}

Initial studies were performed to investigate whether NPYR and NDMA-induced apoptosis in human cancer cells. Thus, cells were treated with 10-50 mM NPYR or 27-135 mM NDMA for different time periods (24-72 h), and nuclear morphology was observed by fluorescence microscopy using acridine orange. 24 hours treatment of HL-60 cells at the highest doses of NPYR $(50 \mathrm{mM})$ and NDMA $(135 \mathrm{mM})$ induced $58 \%$ and $39 \%$ of apoptosis, respectively. In HepG2 cells, $24 \mathrm{~h}$ of treatment with NPYR (50 mM) and NDMA (135 mM), induced above $62-46 \%$ of apoptosis, respectively.

\subsection{TUNEL Assay}

The TUNEL assay is a sensitive test to detect the DNA strand breaks that are a hallmark of the late stages of apoptosis [32]. TUNEL analysis showed that NPYR and NDMA-induced apoptosis in HL-60 (Figure 1) and HepG2 cells (Figure 2), in a concentration and time dependent-manner. An increase in the number of apoptotic (41- 


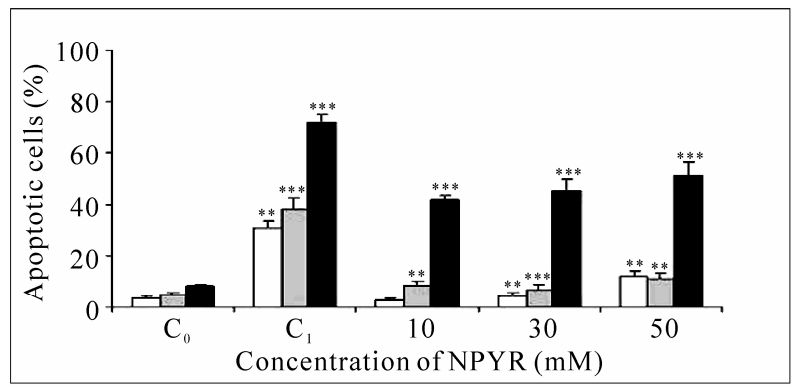

(a)

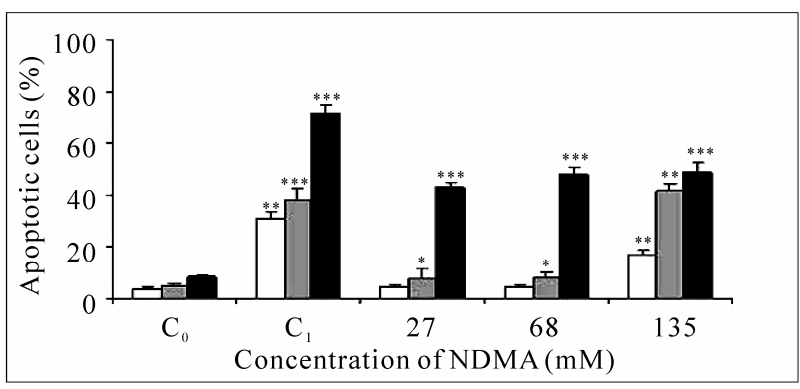

(b)

Figure 1. Flow cytometric analysis using TUNEL assay of HL-60 cells treated with different concentrations of NPYR (a) and NDMA (b) for $24 \mathrm{~h}(\square), 48 \mathrm{~h}(\square)$ and $72 \mathrm{~h}(\square)$. Co, untreated cells; $C_{1}$, cells treated with etoposide $(5 \mu \mathrm{M})$. Asterisks indicate significant difference from control $* * * \mathbf{p}$ $\leq 0.001, * * \mathbf{p} \leq 0.01$ and $* \mathbf{p} \leq \mathbf{0 . 0 5}$.

$51 \%$ ) HL-60 cells was apparent after $72 \mathrm{~h}$ incubation with 10-50 mM NPYR (Figure 1(a)). The short-time treatments (24 and $48 \mathrm{~h}$ ) with NDMA (27 and $68 \mathrm{mM}$ ), did not induce a significant percentage of apoptotic cells (4\%), whereas $72 \mathrm{~h}$ induced about $43-48 \%$, respectively (Figure 1(b)). After treatment with $135 \mathrm{mM}$ of NDMA, an increase in the percentage of apoptotic cells was detected from 48 to $72 \mathrm{~h}$ of incubation (41-49\%, respectively).

The presence of apoptotic cells was noted in HepG2 cells treated with NPYR for $48 \mathrm{~h}$ (24-52\%) (Figure 2(a)). When the cells were treated for $72 \mathrm{~h}$, the highest number of apoptosis was induced with $50 \mathrm{mM}$ of NPYR (68\%).

As shown in Figure 2(b), only a moderate number of TUNEL positive cells were observed after treatment with NDMA for 24 and $48 \mathrm{~h}$. However, at $72 \mathrm{~h}$, a remarkable percentage of apoptotic cells occurred at all concentrations of NDMA. More than $70 \%$ of HepG2 cells were TUNEL positive after treatment with $135 \mathrm{mM}$ of NDMA.

\subsection{Western Blot}

In view of the ability of NPYR and NDMA to induce apoptosis by the TUNEL assay, it was considered of in-

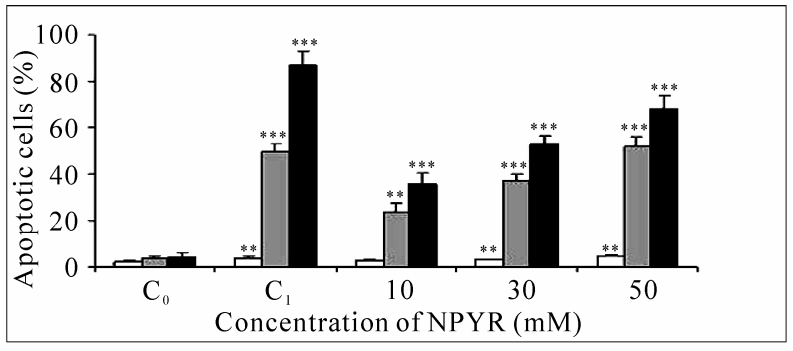

(a)

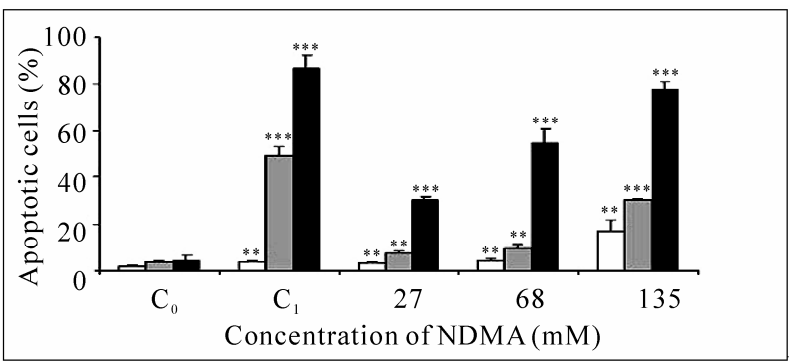

(b)

Figure 2. Flow cytometric analysis using TUNEL assay of HepG2 cells treated with different concentrations of NPYR (a) and NDMA (b) for $24 \mathrm{~h}(\square), 48 \mathrm{~h}(\square)$ and $72 \mathrm{~h}$ ( $\square$ ). Co, untreated cells; $C_{1}$, cells treated with etoposide (100 $\mu M)$. Asterisks indicate significant difference from control $* * * \mathbf{p} \leq \mathbf{0 . 0 0 1}$ and $* * \mathbf{p} \leq \mathbf{0 . 0 1}$.

terest to examine the role of caspases. PARP is a preferential substrate for caspase- 3 and is cleaved by this protein into 85 and $24 \mathrm{KDa}$ fragments during the apoptotic mode of cell death [33]. Thus, protein extracts from HL-60 and HepG2 cells untreated and treated with NPYR, NDMA and etoposide, were electroblotted and probed against a PARP polyclonal antibody that recognizes the $116-\mathrm{kDa}$ intact PARP as well as an $85-\mathrm{kDa}$ cleaved product. Quantification of PARP cleavage was determining by densitometry of the intensity of fulllength protein signal visualized by polyclonal anti-PARP antibody.

As shown in Figure 3, untreated HL-60 cells showed only intact PARP at $116 \mathrm{KDa}$ (Figures 3(a) and 3(b), lane 1). In contrast, all the PARP present in the $5 \mu \mathrm{M}$ etoposide-treated cells had been cleaved into the $85 \mathrm{kDa}$ fragment (Figures 3(a) and 3(b), lane 2). No PARP cleavage was detectable after incubation of cells with 10 mM NPYR (Figure 3(a), lanes 3 and 4). Treatment of HL-60 cells with $30 \mathrm{mM}$ NPYR induced the cleavage of PARP from 116 to $85 \mathrm{kDa}$ at $48 \mathrm{~h}$ (Figure 3(a), lanes 5 and 6). Some uncleaved PARP remained in $50 \mathrm{mM}$ NPYR treated HL-60 cells at $24 \mathrm{~h}$, whereas a PARP cleavage product of $85 \mathrm{kDa}$ was prominent at $48 \mathrm{~h}$ (Figure 3(a), lanes 7 and 8). As shown in Figure 3(b), 


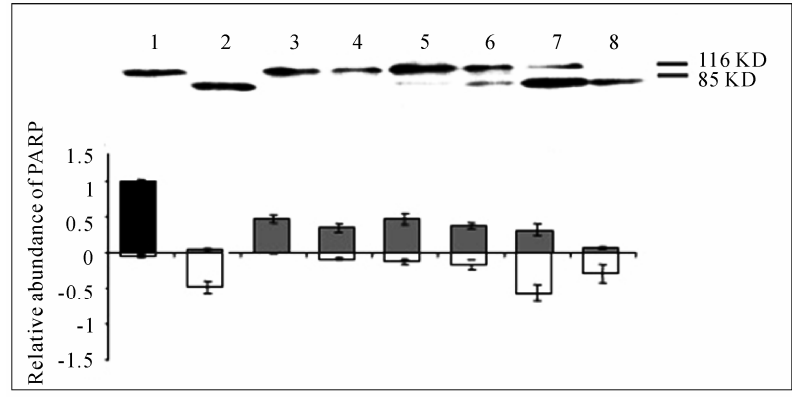

(a)

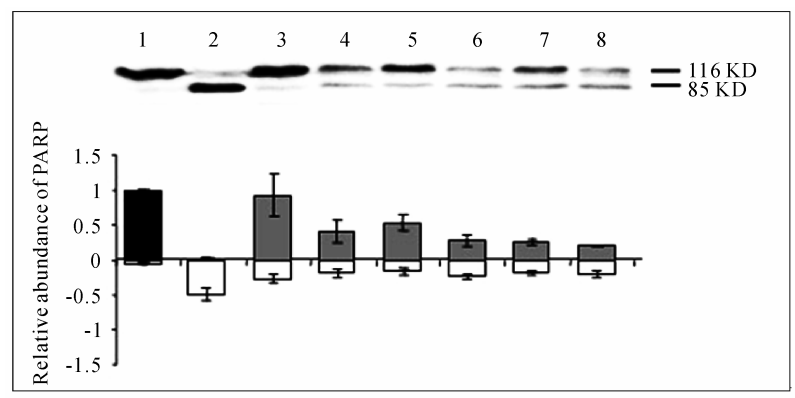

(b)

Figure 3. Western blot of PARP cleavage in HL-60 cells treated with NPYR (a) and NDMA (b). Lane 1 represents untreated cells and lane 2 represents cells treated with etoposide. Lane 3 cells treated with (a) $10 \mathrm{mM}$ or with (b) 27 $\mathrm{mM}$ for $24 \mathrm{~h}$ and lane 4 for $48 \mathrm{~h}$. Lane 5 cells treated with (a) $30 \mathrm{mM}$ or with (b) $68 \mathrm{mM}$ for $24 \mathrm{~h}$ and lane 6 for $48 \mathrm{~h}$. Lane 7 cells treated with (a) $50 \mathrm{mM}$ or with (b) $135 \mathrm{mM}$ for $24 \mathrm{~h}$ and lane 8 for $48 \mathrm{~h}$.

treatment of the cells with NDMA caused the proteolytic cleavage of PARP with accumulation of an $85 \mathrm{KDa}$ fragment and the concomitant disappearance of the original $116 \mathrm{KDa}$ PARP at all test doses.

Figure 4 shows the results obtained in HepG2 cells treated with NPYR and NDMA. In HepG2 cells untreated and treated with etoposide $(100 \mu \mathrm{M}$ for 24 and 72 h), western blot revealed only a single band at $116 \mathrm{KDa}$ representing full-length enzyme (Figures 4(a) and 4(b), lanes 1 and 2). Similarly, PARP cleavage could not be detected after the treatment of HepG2 cells with different doses of NPYR or NDMA for 24 to $72 \mathrm{~h}$ (Figures 4(a) and $\mathbf{4 ( b )}$, lanes 3 to 8 ).

\subsection{Effects of NPYR and NDMA on the Caspase Pathway in HepG2 Cells}

Since the key effector molecules of the apoptotic process belong to the caspase family, we evaluated the ability of NPYR (50 mM, $48 \mathrm{~h})$ and NDMA $(68 \mathrm{mM}, 72 \mathrm{~h})$ to induce apoptosis in HepG2 cells in the presence or absence of different caspase inhibitors $(100 \mu \mathrm{M})$.

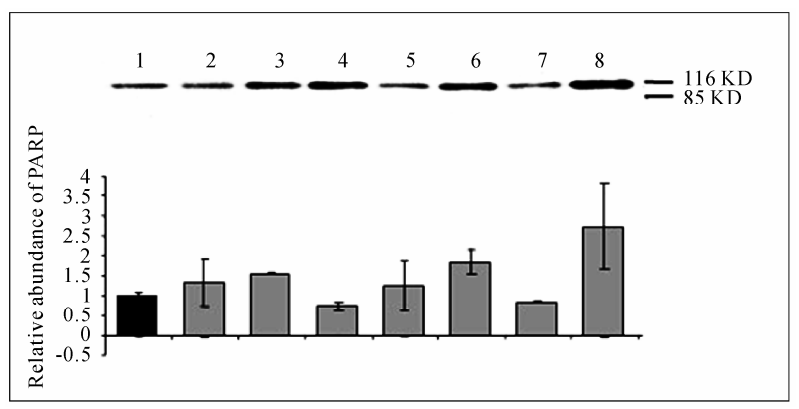

(a)

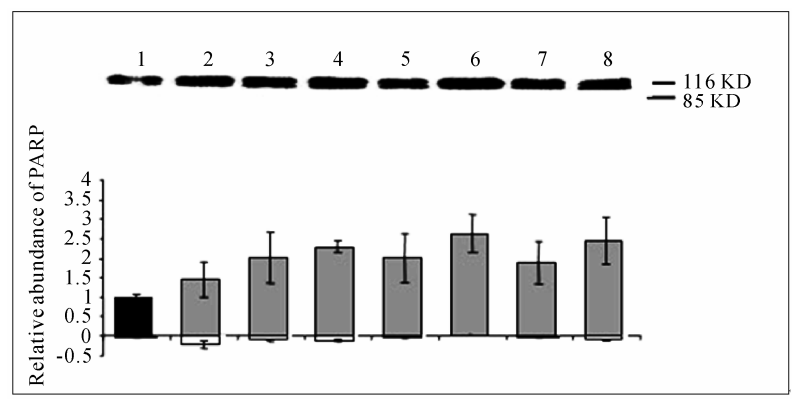

(b)

Figure 4. Western blot of PARP cleavage in HepG2 cells treated with NPYR (a) and NDMA (b). Lane 1 represents untreated cells and lane 2 represents cells treated with etoposide. Lane 3 cells treated with (a) $10 \mathrm{mM}$ or with (b) 27 $\mathrm{mM}$ for $24 \mathrm{~h}$ and lane 4 for $72 \mathrm{~h}$. Lane 5 cells treated with (a) $30 \mathrm{mM}$ or with (b) $68 \mathrm{mM}$ for $24 \mathrm{~h}$ and lane 6 for $72 \mathrm{~h}$. Lane 7 represents cells treated with (a) $50 \mathrm{mM}$ or with (b) 135 $\mathrm{mM}$ for $24 \mathrm{~h}$ and lane 8 for $72 \mathrm{~h}$.

As shown in Figure 5, the addition of Z-IETD-FMK (caspase-8 inhibitor) significantly diminished NPYRand NDMA-induced apoptosis in a 76-64\%, respectively. TheZ-DEVD-FMK (caspase-3 inhibitor) reduced the apoptotic effect of NPYR and NDMA in $79-58 \%$, respectively, and Z-VEID-FMK (caspase-6 inhibitor) inhibited a $63 \%$ both $\mathrm{N}$-nitrosamines. The blockage of apoptosis by Z-LEHD-FMK (caspase-9 inhibitor) caused an inhibition of NPYR- and NDMA-induced apoptosis of 56 and $52 \%$, respectively.

\section{Discussion}

Apoptosis induced by carcinogens seems to have an important role in cancer development [34]. Accordingly, the mechanism and cell signalling pathways involved in food carcinogens-induced cell death or cell survival and proliferation have recently received much interest $[26,35]$. In 1978 the International Agency for Research on Cancer (IARC) classified NPYR and NDMA as possibly and probably carcinogenics to humans, respectively [36]. It is widely accepted that $\mathrm{N}$-Nitrosamines require metabolic 


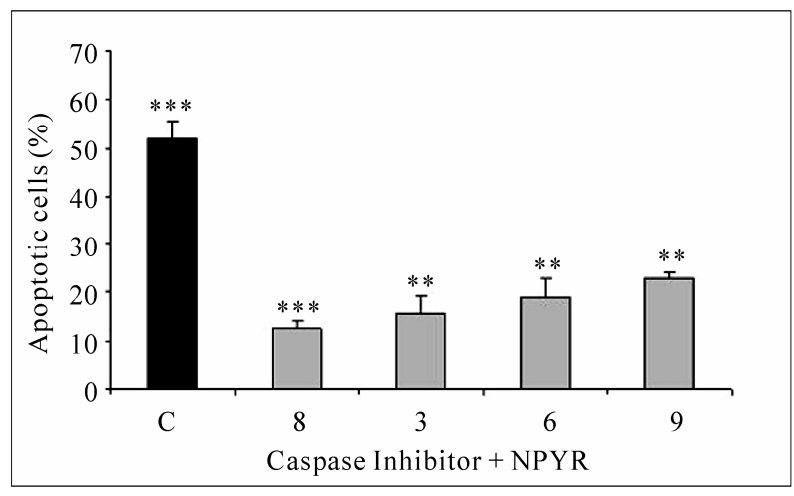

(a)

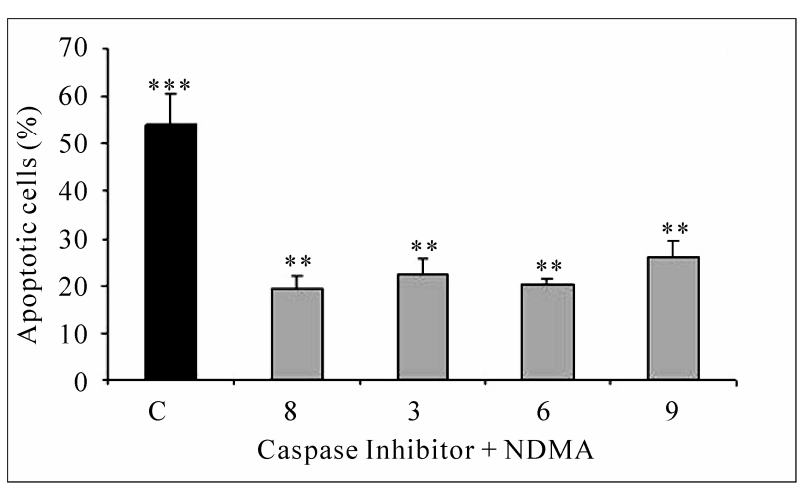

(b)

Figure 5. Effect of specific caspase inhibitor on apoptosis induced by (a) $50 \mathrm{mM}$ NPYR (48 h) or (b) $68 \mathrm{mM}$ NDMA $(72 \mathrm{~h})$ in HepG2 cells, using TUNEL assay and flow cytometry. C ( $\square)$, HepG2 cells treated with N-nitrosamines and without caspase inhibitor. ( $\square$ ) HepG2 cells treated with $\mathrm{N}$-nitrosamines and specific caspase-3, $-6,-8$ or -9 inhibitor. Asterisks indicate significant difference from control $* * * \mathbf{p} \leq \mathbf{0 . 0 0 1}$ and $* * \mathbf{p} \leq \mathbf{0 . 0 1}$.

activation by cytochrome P-450 to become carcinogenic. The activatedN-Nitrosamine attacks and covanlently binds to DNA, forming detectable DNA adducts. Wang et al. [37] showed that there was a significant positive association between NPYR exposures and having detectable several adducts in hepatic DNA of rats. Moreover, Cheng et al. [38] have just demonstrated that NDMA damage calf thymus DNA through reactive metabolites. DNA lesions are converted into double strand breaks that act as a trigger for the up-regulation of $\mathrm{p} 53$, which induces apoptosis by the cell death receptor pathway [39].

In the present study, a variety of methods have been employed to detect and quantify apoptosis, since many studies suggest that the utilisation of two or more different techniques may be convenient to avoid determination errors [40,41]. Our results clearly demonstrated that NPYR and NDMA-induced apoptosis in a concentration and time dependent-manner as judged by the TUNEL assay (Figures 1 and 2). Moreover, we observed that HepG2 cells were more sensitive to the treatments than HL-60 cells. At $72 \mathrm{~h}, 50 \mathrm{mM}$ NPYR induced $51 \%$ of apoptosis in HL-60 and $68 \%$ in HepG2 cells, whereas $135 \mathrm{mM}$ NDMA caused $49 \%$ and $78 \%$ of apoptosis in HL-60 and HepG2 cells, respectively. It has been reported that cell lines differ substantially in their sensitivity towards various classes of apoptotic chemicals [42]. Thus, Duc and Leong-Morgenthaller [43] found that the heterocyclic amine 2-amino-1-methyl-6-phenylimidazo [4, 5-b]pyridine (PhIP) induced different apoptotic response in two human lymphoblastoid cell lines (TK6 and MT1). A five to six fold increase and less than a two fold increase in the fraction of apoptotic cells were observed in TK6 and MT1, respectively. In addition, in our previous studies $[44,45]$ HepG2 cells were more resistant to the apoptosis induction by N-nitrosodibutylamine (NDBA) and N-nitrosopiperidine (NPIP) than HL-60 cell line. $\mathrm{N}$-nitrosamines are metabolised by enzymes of the mixedfunction cytochrome P-450-dependent monooxidase system. Cyclic N-nitrosamines such as NPYR and NPIP are primarily activated by CYP2A6. On the other hand, short chain N-nitrosamines such as NDMA is activated by CYP2E1 whereas CYP1A1 is involved in the metabolism of the longer chain N-nitrosamines such as NDBA [46]. Thus, a possible explanation of the variation in the percentage of apoptotic cells induced by N-nitrosamines could be attributed to the differences in the levels of enzymatic activities in both cell lines.

Both N-nitrosamines induce apoptosis in HL-60 and HepG2 cells, even though NPYR was most effective than NDMA at lower concentration. Numerous studies have reported that genotoxicity of NDMA in human hepatoma cell lines was observed only at high concentrations [47, 48]. Furthermore, we have demonstrated that NPYR exerted greater oxidative DNA damage in HepG2 cells than NDMA by using the Comet assay [49]. The lowest concentration of NDMA required to cause a significant increase in DNA damage was approximately 5-fold higher than that of the corresponding NPYR. In comparison with our previous studies $[44,45]$ NDBA was the most effective $\mathrm{N}$-nitrosamine to induce apoptosis in both cell lines by the TUNEL assay. Thus, after $24 \mathrm{~h}$ incubation with NDBA at $3.5 \mathrm{mM}$, the percentage of apoptotic HepG2 cells reached 95\%, whereas it was necessary to use doses of $45 \mathrm{mM}$ NPIP (86\%), $50 \mathrm{mM}$ NPYR (68\%) and $135 \mathrm{mM}$ NDMA (77\%) and longer incubations times (72 h) to obtain a high percentage of apoptotic HepG2 cells. Similar findings have been obtained in the leukemia HL-60 cell line. At 72 h, $2.5 \mathrm{mM}$ NDBA induced $69 \%$ of apoptotic HL-60 cells, whereas it was necessary doses of $20 \mathrm{mM}$ NPIP (75\%), $50 \mathrm{mM}$ NPYR (51\%) and 
$135 \mathrm{mM}$ NDMA (49\%) to obtain a high percentage of apoptotic cells. The fact that the percentage of apoptotic cells varied with the type of N-nitrosamine suggests that the apoptotic effect depended on the chemical structure of N-nitrosamine.

Activated caspase-3 cleaves PARP, a $116 \mathrm{kDa}$ enzyme, generating a fragment of $85 \mathrm{kDa}$ [50]. Our results showed that NPYR and NDMA caused PARP cleavage in HL-60 cells, in a concentration and time dependent manner (Figure 3). In contrast, no PARP cleavage (reflecting caspase-3 activation) was detected in HepG2 cells (Figure 4). These results are in agreement with Dibartolomeis and Moné [51] who assumed that the PARP cleavage was based on the disappearance of the $116 \mathrm{kDa}$ fragment in Jurkat cells treated with with $500 \mu \mathrm{M}$ etoposide.

To determine whether the caspases were involved in NPYR and NDMA-induced apoptosis in HepG2 cells, we also analysed the effects of the specific inhibitors of caspase activity. The two major apoptotic pathways described in eukaryotic cells are extrinsic (triggered by death receptors) and intrinsic mediated by mitochondrial events [52]. The apical proteases in the extrinsic and intrinsic pathways are caspase- 8 and caspase- 9 , respectively. Activated caspase- 8 and -9 further initiates the activation of caspase cascade leading to biochemical and morphological changes associated with apoptosis [53]. Caspase-3 and -6 are well-known downstream effector caspases which can be proteolytically activated by caspase-8 or -9 via different signalling pathways [54].

Our results confirmed that NPYR and NDMA-induced cell death in HepG2 cells was due to caspase-dependent apoptosis (Figure 5). Caspase-8 seems to be the central caspase in the NPYR and NDMA-induced apoptosis because blocking of its activity had the highest percentage of reduction of apoptosis (76-64\%, respectively). Inhibition of caspase- 3 and -6 activities partially inhibited the NPYR and NDMA-induced apoptosis which suggested that caspase- 8 was upstream of caspase-3 and - 6 . However, may be other mechanism for caspase- 3 and -6 activations, apart from the cascade mediated through caspase- 8 activation [55]. Caspase-9 activity was slightly reduced by the inhibitor, suggesting the involvement of intrinsic pathway, but might not be the major way to induce apoptosis in HepG2 cells. It is now recognized that some chemicals induce apoptosis via the mitochondria-dependent pathway in which caspase-9 is initially activated [56] and also activate caspase- 8 in the absence of the death receptor signalling [57]. Our results are consistent with the report in which heterocyclic amine, 3Amino-1,4-dimethyl-5H-pyrido-[4,3-b]indole (Trp-P-1)induced apoptosis, mainly operates the caspase-8-depen- dent pathway, and there is also a caspase-9-dependent side pathway [21]. Moreover, we found that both the intrinsic and extrinsic pathways were similarly involved in the NPIP and NDBA-induced apoptosis in HepG2 cells [45].

Taken together, the results reported in this work demostrate that NPYR and NDMA induce apoptosis in HepG2 and HL-60 cell lines via caspase dependent pathway. Further studies are needed to determine the molecular mechanism of NPYR and NDMA induce apoptosis.

\section{Acknowledgements}

This work has been supported by Grant ALI2002-01033 from the Ministerio de Ciencia y Tecnología (Spain) and by Grant 910177 from the Comunidad de Madrid and the Universidad Complutense (UCM). N. Arranz is recipient of Fellowship from the Ministerio de Ciencia y Tecnología, Spain.

\section{REFERENCES}

[1] S. S. Mirvish, "Role of N-nitroso Compounds (NOC) and $\mathrm{N}$-nitrosation in Etiology of Gastric, Esophageal, Nasopharyngeal and Bladder Cancer and Contribution to Cancer of Known Exposures to NOC," Cancer Letters, Vol. 93, No. 1, 1995, pp. 17-48.

[2] L. Cardenes, J. H. Ayala, V. González and A. M. Afonso, "Fast Microwave-Assisted Dansylation of N-nitrosamines Analysis by High-Performance Liquid Chromatography with Fluorescent Detection," Journal of Chromatography, Vol. 946, No. 1-2, 2002, pp. 133-140.

[3] I. T. Vermeer, E. J. Moonen, J. W. Dallinga, J. C. Kleinjans and J. M. van Maanen, "Effect of Ascorbic Acid and Green Tea on Endogenous Formation of N-nitrosodimethylamine and N-nitrosopiperidine in Humans," Mutation Research, Vol. 428, No. 1-2, 1999, pp. 353-361.

[4] R. Andrade, F. G. R. Reyes and S. Rath, "A Method for the Determination of Volatile N-nitrosamines in Food by HS-SPME-GC-TEA," Food Chemistry, Vol. 91, No. 1, 2005, pp. 173-179.

[5] R. Gray, R. Peto, P. Brantom and P. Grasso, "Chronic Nitrosamine Ingestion in 1040 Rodents: The Effect of the Choice of Nitrosamine, The Species Studied, and the Age of Starting Exposure," Cancer Research, Vol. 51, No. 23, 1991, pp. 6470-6491.

[6] M. Greenblatt and W. Lijinsky, "Failure to Induce Tumors in Swiss Mice after Concurrent Administration of Amino Acids and Sodium Nitrite," Journal of the National Cancer Institute, Vol. 48, No. 5, 1972, pp. 13891392.

[7] R. Preussmann and B. W. Stewart, "N-nitroso Carcinogens," In: C. E. Searle, Ed., Chemical Carcinogens, American Chemical Society, Washington, D.C., 1984, pp. 643-828.

[8] D. Y. Lai and J. C. Arcos, "Minireview: Dialkylnitrosa- 
mine Bioactivation and Carcinogenesis," Life Sciences, Vol. 27, No. 23, 1980, pp. 2149-2165.

[9] H. L. Wong, S. E. Murphy and S. S. Hecht, "Comparative Metabolism of N-nitrosopiperidine and N-nitrosopyrrolidine by Rat Liver and Esophageal Microsomes and Cytochrome P450 2A3," Carcinogenesis, Vol. 24, No. 2, 2003, pp. 291-300.

[10] M. Leist, B. Single, A. F. Castoldi, S. Kuhnle and P. Nicotera, "Intracellular Adenosine Triphosphate (ATP) Concentration: A Switch in the Decision between Apoptosis and Necrosis," Journal of Experimental Medicine, Vol. 185, No. 8, 1997, pp. 1481-1486.

[11] A. H. Wyllie, J. F. R. Kerr and A. C. Currie, "Cell Death: The Significance of Apoptosis," International Review of Cytology, Vol. 68, 1980, pp. 251-305.

[12] S. H. Kaufmann and G. J. Gores, "Apoptosis in Cancer: Cause and Cure," Bioessays, Vol. 22, No. 11, 2000, pp. 1007-1017.

[13] L. Hegyi, S. J. Hardwick, R. C. M. Siow and J. N. Skepper, "Macrophage Death and the Role of Apoptosis in Human Atherosclerosis," Journal of Hematotherapy \& Stem Cell Research, Vol. 10, No. 1, 2001, pp. 27-42.

[14] D. J. Granville, C. M. Carthy, H. Jiang, G. C. Shore, B. M. McManus and D. W. Hunt, "Rapid Cytochrome c Release, Activation of Caspases 3, 6, 7 and 8 followed by Bap31 Cleavage in HeLa Cells Treated with Photodynamic Therapy," FEBS Letters, Vol. 437, No. 1-2, 1998, pp. 5-10.

[15] A. H. Wyllie, G. J. Beattie and A. D. Hargreaves, "Chromatin Changes in Apoptosis," The Histochemical Journal, Vol. 13, No. 4, 1981, pp. 681-692.

[16] D. L. Vaux, "Immunopathology of Apoptosis-Introduction and Overview," Semininars in Inmunopathology, Vol. 19, No. 3, 1998, pp. 271-278.

[17] G. Kroemer, "Mitochondrial Implication in Apoptosis. Towards an Endosymbiotic Hypothesis of Apoptosis Evolution," Cell Death and Differentiation, Vol. 4, No. 6, 1997, pp. 443-456.

[18] A. Anel, S. Gamen, M. A. Alava, A. M. Schmitt-Verhulst, A. Pineiro and J. Naval, "Inhibition of CPP32-Like Proteases Prevents Granzyme B- and Fas-, but not Granzyme A-Based Cytotoxicity Exerted by CTL Clones," Immunology, Vol. 158, No. 5, 1997, pp. 1999-2006.

[19] C. E. Schwab and H. Tuschl, "In vitro Studies on the Toxicity of Isoniazid in Different Cell Lines," Human \& Experimental Toxicology, Vol. 22, No. 11, 2003, pp. 607615.

[20] V. M. Salas and S. W. Burchiel, "Apoptosis in Daudi Human B cells in Response to Benzo[a] pyrene and Benzo [a] pyrene-7,8-dihydrodiol," Toxicology and Applied Pharmacology, Vol. 151, No. 2, 1998, pp. 367-376.

[21] H. Ashida, K. Kihara, Y. Nonaka, I. Fukuda, B. Shiotani and T. Hashimoto, "The Heterocyclic Amine, 3-amino-1, 4-dimethyl-5H-pyrido[4,3-b]indole Induces Apoptosis in Cocultures of Rat Parenchymal and Nonparenchymal Liver Cells," Toxicology and Applied Pharmacology, Vol. 177, No. 1, 2001, pp. 59-67.
[22] T. Hashimoto, H. Ashida, T. Sano, T. Furuyashiki, Y. Hatanaka, K. Minato, M. Mizuno, K. Nomura, A. Kumatori, K. Kanazawa and G. Danno, "3-Amino-1,4-dimethyl -5H-pyrido[4,3-b]indole (Trp-P-1) Induces Caspase-Dependent Apoptosis in Mononuclear Cells," Biochimica et Biophysica Acta, Vol. 1539, No. 1-2, 2001, pp. 44-57.

[23] S. H. Moon, H. W. Kim, J. S. Kim, J. H. Park, H. Kim, G. J. Eu, H. S. Cho, G. M. Kang, K. H. Lee and M. H. Cho, "Cap-Independent Protein Translation is Initially Responsible for 4-(N-methylnitrosamino)-1-(3-pyridyl)-butanone (NNK)-induced Apoptosis in Normal Human Bronchial Epithelial Cells," Journal of Veterinary Science, Vol. 5, No. 4, 2004, pp. 369-378.

[24] J. A. Holme, M. Gorria, V. M. Arlt, S. Ovrebø, A. Solhaug, X. Tekpli, N. E. Landvik, L. Huc, O. Fardel and D. Lagadic-Gossmann, "Different Mechanisms Involved in Apoptosis Following Exposure to Benzo[a]pyrene in F258 and Hepa1c1c7 Cells," Chemico Biological Interactions, Vol. 167, No. 1, 2007, pp. 41-55.

[25] J. Jablonski, E. Jablonska and M. Chojnowski, “The Influence of Very Low Doses of N-nitrosodimethylamine (NDMA) on the Apoptosis of Rat Neutrophils in vivo, the Role of Reactive Oxygen Species," Toxicology, Vol. 165, No. 1, 2001, pp. 65-74.

[26] H. L. Lin, L. A. Parsels, J. Maybaum and P. F. Hollenberg, "N-Nitrosodimethylamine-mediated Cytotoxicity in a Cell Line Expressing P450 2E1: Evidence for Apoptotic Cell Death," Toxicology and Applied Pharmacology, Vol. 157, No. 2, 1999, pp.117-124.

[27] H. Doostdar, M. H. Grant, W. T. Melvin, C. R. Wolf and M. D. Burke, "The Effects of Inducing Agents on Cytochrome P450 and UDP-glucuronyltransferase Activities in Human HEPG2 Hepatoma Cells," Biochemical Pharmacology, Vol. 46, No. 4, 1993, pp. 629-635.

[28] J. A. Holme, R. Wiger, J. K. Hongslo, E. Soderlund, G. Brunborg and E. Dybing, "Cell Death via Interactions of Agents with DNA," Molecular and Cellular Biology, Vol. 20, 1997, pp. 145-182.

[29] F. Nagai, Y. Hiyoshi, K. Sugimachi and H. Tamura, "Cytochrome P450 (CYP) Expression in Human Myeloblastic and Lymphoid Cell Lines," Biological and Pharmaceutical Bulletin, Vol. 25, No. 3, 2002, pp. 383385.

[30] J. B. Custodio, C. M. Cordoso and L. M. Almeida, "Thiol Protecting Agents and Antioxidants Inhibit the Mitochondrial Permeability Transition Promoted by Etoposide: Implications in the Prevention of Estoposide-Induced Apoptosis," Chemico Biological Interactions, Vol. 140, 2002, pp. 169-184.

[31] C. D. Gregory, C. Dive, S. Henderson, C. A. Smith and G. T. Williams, "Activation of Epstein-Barr Virus Latent Genes Protects Human B Cells from Death by Apoptosis," Nature, Vol. 349, No. 6310, 1991, pp. 612-614.

[32] K. U. Frohlich and F. Madeo, "Apoptosis in Yeast, a Monocelular Organism Exhibits Altruistic Behaviour," FEBS Letters, Vol. 473, No. 1, 2000, pp. 6-9.

[33] S. H. Kaufmann, S. Desnoyers, Y. Ottaviano, N. E. 
Davidson and G. G. Poirier, "Specific Proteolytic Cleavage of Poly-(Adpribose) Polymerase: An Early Marker of Chemotherapy Induced Apoptosis," Cancer Research, Vol. 53, No. 17, 1999, pp. 3976-3985.

[34] T. Rich, R. L. Allen and A. H. Wyllie, "Defying Death after DNA damage," Nature, Vol. 407, No. 6805, 2000, pp. 777-783.

[35] N. E. Landvik, M. Gorria, V. M. Arlt, N. Asare, A. Solhaug, D. Lagadic-Gossmann and J. A. Holme, "Effects of Nitrated-Polycyclic Aromatic Hydrocarbons and Diesel Exhaust Particle Extracts on Cell Signalling Related to Apoptosis: Possible Implications for their Mutagenic and Carcinogenic Effects," Toxicology, Vol. 231, No. 2-3, 2007, pp. 159-174.

[36] IARC, "Some N-nitroso Compounds," In: IARC Monographs on the Evaluation of the Carcinogenic Risk of Chemical to Humans, International Agency for Research on Cancer, Lyon, 1978, p. 17.

[37] M. Wang, Y. Lao, G. Cheng, Y. Shi, P. W. Villalta, A. Nishikawa and S. S. Hecht, "Analysis of Adducts in Hepatic DNA of Rats Treated with N-nitrosopyrrolidine," Chemical Research in Toxicology, Vol. 20, No. 4, 2007, pp. 634-640.

[38] G. Cheng, M. Wang, P. Upadhyaya, P. W. Villalta and S. S. Hecht, "Formation of Formaldehyde Adducts in the Reactions of DNA and Deoxyribonucleosides with Alphaacetates of 4-(methylnitrosamino)-1-(3-pyridyl)-1-butanone (NNK), 4-(methylnitrosamino)-1-(3-pyridyl)-1-butanol (NNAL) and N-nitrosodimethylamine (NDMA)," Chemical Research in Toxicology, Vol. 21, No. 3, 2008, pp. 746-751.

[39] W. P. Roos, M. Baumgartner and B. Kaina, "Apoptosis Triggered by DNA Damage O6-methylguanine in Human Lymhocytes Requires DNA Replication and is Mediated by p53 and Fas/CD95/Apo-1," Oncogene, Vol. 23, No. 2, 2004, pp. 359-367.

[40] G. Del Bino, Z. Darzynkiewicz, C. Degraef, R. Mosselmans, D. Fokan and P. Galand, "Comparison of Methods Based on Annexin-V Binding, DNA Content or TUNEL for Evaluating Cell Death in HL-60 and Adherent MCF-7 Cells," Cell Proliferation, Vol. 32, No. 1, 1999, pp. 2537.

[41] M. J. Gomez-Lechón, E. O'Connor, J. V. Castell and R. Jover, "Sensitive Markers Used to Identify Compounds That Trigger Apoptosis in Cultured Hepatocytes," Toxicology Sciences, Vol. 65, No. 2, 2002, pp. 299-308.

[42] T. Hashimoto, H. Ashida, T. Sano, T. Furuyashiki, B. Shiotani, K. Kanazawa and G. Danno, "3-Amino-1,4-dimethyl-5H-pyrido[4,3-b]indole (Trp-P-1) Induces Apoptosis in Rat Splenocytes and Thymocytes by Different Mechanisms," Mutation Research, Vol. 457, No. 1-2, 2000, pp. 57-67.

[43] R. Duc and P. M. Leong-Morgenthaller, "Heterocyclic Amine Induced Apoptotic Response in the Human Lymphoblastoid Cell Line TK6 is Linked to Mismatch Repair status," Mutation Research, Vol. 486, No. 2, 2001, pp. 155-164.
[44] A. García, P. Morales, N. Arranz, E. Delgado, J. Rafter, A. I. Haza, "Induction of Apoptosis and Reactive Oxygen Species Production by N-nitrosopiperidine and N-nitrosodibutylamine in Human Leukemia Cells," Journal of Applied Toxicology, Vol. 28, No. 4, 2007, pp. 455-465.

[45] A. García, P. Morales, J. Rafter and A. I. Haza, "N-nitrosopi-peridine and N-nitrosodibutylamine Induce Apoptosis in Hepg2 Cells via the Caspase Dependent Pathway," Cell Biology International, Vol. 33, No. 12, 2009, pp. 1280-1286.

[46] K. I. Fujita and T. Kamataki, "Role of Human P450 (CYP) in the Metabolic Activation of N-alkylnitrosamines: Application of Genetically Engineered Salmonella Typhimurium YG7108 Expressing Each Form of CYP Together with Human NADPH-cytochrome P450 Reductase," Mutation Research, Vol. 483, No. 1-2, 2001, pp. $35-41$.

[47] I. Valentin-Severin, L. Le Hegarat, J. C. Lhuguenot, A. M. Le Bon and M. C. Chagnon, "Use of Hep G2 Cell Line for Direct or Ondirect Mutagens Screening: Comparative Investigation between Comet and Micronucleus Assays," Mutation Research, Vol. 536, No. 1-2, 2003, pp. 79-90.

[48] B. J. Majer, V. Mersch-Sundermann, F. Darroudi, B. Laky, K. de Wit and S. Knasmüller, "Genotoxic Effects of Dietary and Lifestyle Related Carcinogens in Human Derived Hepatoma (HepG2, Hep3B) Cells," Mutation Research, Vol. 551, No. 1-2, 2004, pp. 153-166.

[49] N. Arranz, A. I. Haza, A. García, J. Rafter and P. Morales, "Protective Effects of Organosulfur Compounds towards N-nitrosamines-induced DNA Damage in the Single-Cell Gel Electrophoresis (SCGE/HepG2 Assay," Food and Chemical Toxicology, Vol. 45, No. 9, 2007, pp. 16621669.

[50] Y. Weinrauch and A. Zychlinsky, "The Induction of Apoptosis by Bacterial Pathogens," Annual Review of Microbiology, Vol. 53, No. 1, 1999, pp. 155-187.

[51] S. M. DiBartolomeis and J. P. Moné, "Apoptosis: A Four-Week Laboratory Investigation for Advanced Molecular and Cellular Biology Students," Cell Biology and Education, Vol. 2, No. 4, 2003, pp. 275-295.

[52] F. H. Igney and P. H. Krammer, "Death and Anti-Death: Tumor Resistance to Apoptosis," Nature Reviews Cancer, Vol. 2, No. 4, 2002, pp. 277-288.

[53] C. G. Tepper, M. F. Seldin and M. Mudryi, "Fas- Mediated Apoptosis of Proliferating, Transiently Growth- Arrested, and Senescent Normal Human Fibroblasts," Experimental Cell Research, Vol. 260, No. 1, 2000, pp. 9-19.

[54] G. M. Cohen, "Caspases: The Executioners of Apoptosis," Journal of Biological Chemistry, Vol. 326, 1997, pp. 1-16.

[55] S. H. Oh and B. H. Lee, "Induction of Apoptosis in Human Hepatoblastoma Cells by Tetrandrine via CaspaseDependent Bid Cleavage and Cytochrome c Release," Biochemistry \& Pharmacology, Vol., 66, No. 5, 2003, pp. 725-731.

[56] C. M. Wolf and A. Eastman, "The Temporal Relationship 
between Protein Phosphatase, Mitochondrial Cytochrome c Release, and Caspase Activation in Apoptosis," Experimental Cell Research, Vol. 247, No. 2, 1999, pp. 505-513.

[57] S. Wesselborg, I. H. Engels, E. Rossmann, M. Los and K.
Schulze-Osthoff, “Anticancer Drugs Induce Caspase-8/ FLICE Activation and Apoptosis in the Absence of CD95 Receptor/Ligand Interaction," Blood, Vol. 93, No. 9, 1999, pp. 3053-3063. 